\title{
Lipoxygenases, Hyaluronidase, and Xanthine Oxidase Inhibitory Effects Extracted from Five Hydrocotyle Species
}

\author{
Seok Hyeon Moon ${ }^{1, *}$, Yong $\operatorname{Lim}^{2, * *}$ and Man Kyu Huh ${ }^{1, ;, * *}$ \\ ${ }^{1}$ Food Science \& Technology Major, Dong-eui University, Busan 47340, Korea \\ ${ }^{2}$ Department of Clinical Laboratory Science, Dong-eui University, Busan 47340, Korea
}

\begin{abstract}
Hydrocotyle is a genus of prostrate, perennial aquatic or semi-aquatic plants formerly classified in the family Apiaceae, now in the family Araliaceae. Lipoxygenases (LOX) are present in the human body and play an important role in the stimulation of inflammatory reactions. Ethanolic extracts of five Hydrocotyle species (H. ramiflora, H. maritima, $H$. nepalensis, H. sibthorpioides, and H. yabei) showed inhibition of $23.5 \sim 50.6 \%$ at $2.0 \mathrm{mg} / \mathrm{mL}$. Their extracts showed LOX inhibition in half maximal effective concentration $\left(\mathrm{EC}_{50}\right)$ range $15.1 \sim 15.7 \mu \mathrm{g} / \mathrm{mL}$. Hyaluronic acid is a glycosaminoglycan, a major component of the extracellular matrix Five extracts of these species inhibited less than $23.0 \%$ of Hyaluronidase (HAase) activity at a concentration of $2.0 \mathrm{mg} / \mathrm{mL}$ Xanthine oxidase (XO) is a form of xanthine oxidoreductase, a type of enzyme that generates reactive oxygen species. Five Hydrocotyle species were found to have inhibitory activity of XO at $2.0 \mathrm{mg} / \mathrm{ml}$, with $65 \%$ having greater than $50 \%$ inhibition. H. ramiflora exhibited the highest activity with an inhibition of $80.0 \%$. The results suggested that Lipoxygenases, Hyaluronidase, and Busan 47340, Republic of Korea from five Hydrocotyle species might be multifunctional and prevent the degradation of allergic reactions and inflammation.
\end{abstract}

Key Words: Hydrocotyle, Lipoxygenases, Hyaluronidase, Xanthine oxidase, $\mathrm{EC}_{50}$

\section{서 론}

염증이란 외부로부터의 감염 및 생체 조직 손상에 대 해 체내에서 일어나는 방어적 반응으로 면역세포를 포함 한 혈관, 분자적 방어기작 등 인체가 문제를 해결하도록 신호를 보내고 유지해주는 현상이다(Ferrero-Miliani et al, 2007). 일반적인 증상은 열(calor), 통증(dolor), 부종(tumor), 홍반(rubor)이 있으며 문제가 해결되지 않은 경우 심하면 기능의 소실을 초래하게 된다(Lawrence et al., 2002). 염증 성 단백질이 온몸에 계속 쌓이면 각종 질환을 직·간접적 으로 유발한다. 알레르기, 동맥경화, 자가면역질환, 치매, 안질환, 심지어는 암도 질병 과정에 염증이 관여하고 있
다는 것이 인식되고 있다(Gracie et al., 1999; Kinne et al., 2000; Reilly et al., 2004; Milando et al., 2020).

리폭시게나아제(Lipoxygenase, LOX, EC 1.13.11.-)는 아 라키돈산(arachidonic acid)으로부터 염증과 알레르기 증상 유발 물질인 prostaglandin 류와 류코트리엔(leukotriene) 류 를 만들어내는 과정을 촉매한다(Fan and Chapkin, 1998; Kim et al., 2007). 류코트리엔(leukotriene) 경로에 관여하는 LOX에는 5-LOX, 12-LOX 및 15-LOX가 있으며(Samuelsson et al., 1987; Yedgar et al., 2007), 류코트리엔이 과도하게 생성 될 경우 아토피, 알레르기성 비염, 천식과 같은 알레르기 질환의 원인이 된다(Lee and Ryu, 2000; Natarajan and Nadler, 2004; Kuhn and O'Donnell, 2006).

히알루론산(Hyaluronic acid, HA)은 신체의 연골, 피부 등

Received: October 14, 2021 / Revised: November 23, 2021 / Accepted: November 25, 2021

* Graduate student, ${ }^{* *}$ Professor.

$\dagger$ Corresponding author: Man Kyu Huh. Food Science \& Technology Major, Dong-eui University, Busan 47340, Korea.

Tel: +82-51-890-1592, Fax:+82-010-8334-8592, e-mail: mkhuh@deu.ac.kr

(C) The Korean Society for Biomedical Laboratory Sciences. All rights reserved.

(2) This is an Open Access article distributed under the terms of the Creative Commons Attribution Non-Commercial License (http://creativecommons.org/licenses/by-nc/3.0/) which permits unrestricted non-commercial use, distribution, and reproduction in any medium, provided the original work is properly cited. 
결합조직에 존재하는 고분자 물질로 대식세포의 식작용 을 억제하여 염증반응을 조절하는 작용을 한다(Girish and Kemparaju, 2007). HA의 분해효소인 Hyaluronidase (HAase, $\mathrm{EC}$ 3.2.1.35)는 류마티스 관절염 같은 염증 질환 시 활성 화되고 알레르기 유발, 암 전이 등과의 연관성이 보고된 바 있다(Goggins et al., 1968; Bertolami and Donoff, 1978). HAase 저해에 의해 HA의 고분자 형태를 유지하게 함으 로써 항염증 효과를 기대할 수 있다(Ghosh, 1994).

크산틴 산화효소(Xanthine oxidase, EC 1.2.3.2)는 생체 내 퓨린대사에 관여하는 효소로 xanthine을 기질로 하여 uric acid를 생성하는 과정에서 superoxide radical을 생성하는 효소이다(Ziegler et al., 1971; Duke et al., 1973). 요산이 혈액 중에서 이상 증가로 관절낭에 축적되면 염증을 유발하며, 통풍 및 심한 경우 신장이나 심장에 합병증을 유발하기 도 한다(Storch and Ferber, 1988). 한편 xanthine oxidase 저 해제는 통풍, 요산혈증에 대한 치료제로 사용되어 왔으 며 allopurinol, alloxanthine, probenecid 등이 알려져 있으나 (Gilman et al., 1985), 치료제 내성 유발, 항암제 대사 억제, 재생불량성 빈혈 등의 부작용이 있다.

한국에서 피막이의 이름은 피를 멈추게 하는 용도로 사 용되었는데, 피막이속(Hydrocotyle) 식물의 잎이 지혈제로 사용되었다. 피막이속 식물의 추출물은 Chloramphenicol에 비해 약간 낮은 항균 활성을 나타냈다(Handique and Garg, 2015). 또한 총 페놀 화합물, 플라보노이드 및 플라보놀의 존재가 라디칼 소거 특성을 포함한 광범위한 화학 및 생 물학적 활성과 관련된 피막이속 식물이 보고되었다(Chan et al., 2009). 피막이의 연구로 밝혀진 생리활성으로는 항 산화, 항증식, 항균 등 간염에의 효과가 알려져 있으며 (Farong et al., 2007), 항혈전 효능에 대해서는 연구가 부족 한 실정이다.

본 연구는 in vitro test로서 한국산 피막이 5종에 대한 항알레르기 효능과 밀접하게 관련된 $15-\mathrm{LOX}$ 의 억제능, 고분자 HAase 저해를 통한 항염증 효과, 항통풍성 소재 탐색을 위한 xanthine oxidase 저해효과를 살펴보았다.

\section{재료 및 방법}

\section{시약 및 기기}

피막이속에는 큰피막이(Hydrocotyle ramiflora), 큰잎피 막이(H. nepalensis), 선피막이(H. maritima), 제주피막이(H. $y a b e i)$ 의 5종이 있으며 전라남도 무안군 청계면, 경상남도 사천시 곤명면, 울산광역시 울주군 삼납읍, 부산광역시
금정구 장전동, 제주도 서귀포시 성산읍 성산포 일원에서 채취하여 실험재료로 사용하였다. 채취한 Hydrocotyle 속 5 종은 세척 후 마쇄하여 각각 무게 당 10 배의 $70 \%$ 에탄 올을 가하여 24시간 교반하여 유효성분을 추출하였다. 추 출액은 Whatman filter paper No 1로 거른 뒤 회전식 진공 증발기(N-1001S-W, Eyela, Tokyo, Japan)를 사용하여 감압 하고 온도를 조절하여 용매를 제거하였다. 그 후, 건조 분말을 얻기 위해 샘플을 진공 챔버에 넣고 저온에 두었 다. 동결 건조하여 분말 시료를 실험에 사용하였다.

실험을 위하여 사용된 시약은 15-LO inhibitor screening assay kit (Cayman Chemical Co., Ann Arbor, MI, USA)이며, xanthine, xanthine oxidase, nordihydroguaiaretic acid (NDGA), hyaluronidase, hyaluronic acid, p-dimethylaminobenzaldehyde (DMAB), Calcium chloride, potassiumtetraborate, sodium hydroxide, trichloroacetic acid (TCA) 등은 Sigma사(St. Louis, USA)에서 구입하였다.

본 실험에서 사용한 주요 기기는 centrifuge (UNION 32R, Hanil Science Industrial Co., Korea), $\mathrm{CO}_{2}$ incubator (MCO 175, Sanyo Electric Co., Japan), water bath (C-WB, CHANG SHIN Scientific Co., Korea)를 사용하였다. ELISA autoreader는 VERSA max (Molecular devices Co., Sunnyvale, USA) 모델을 사용하였다.

\section{5-Lipoxygenase (15-LO) 저해활성 측정}

115-LO 저해활성 측정은 $15-\mathrm{LO}$ inhibitor screening assay kit (Abnova, CA, USA)의 매뉴얼에 따랐다. 샘플 $10 \mu \mathrm{L}$ 에 $15-\mathrm{LO}$ (220 units/ml) $90 \mu \mathrm{L}$ 와 $1 \mathrm{mM}$ 아라키돈산 $10 \mu \mathrm{L}$ 을 첨 가하여 5 분 간 상온에서 반응시킨 후, 색원체(chromogen) $100 \mu \mathrm{L}$ 를 가하여 상온에서 5 분 동안 반응시키고 ELISA autoreader를 사용하여 $490 \mathrm{~nm}$ 에서 흡광도를 측정하였다. 이때 양성대조군으로 nordihydroguaiaretic acid을 사용하 였다.

\section{Hyaluronidase (HAase) 저해활성 측정}

HAase 저해활성은 sodium-hyaluronic acid (HA)로부터 형 성된 N-acetylglucosamine을 glucoxazoline 유도체로 변형시 킨 후 p-dimethylaminobenzaldehyde (DMAB)로 발색시켜 흡광도를 측정하여 효소 활성을 측정하였다(Reissig et al., 1995). 0.1 M acetate buffer (pH 3.5)에 녹인 HAase (7,900 U/ $\mathrm{mL}) 0.05 \mathrm{~mL}$ 와 시료 용액 $0.1 \mathrm{~mL}$ 를 혼합하여 $37^{\circ} \mathrm{C}$ 에서 20 분간 배양한 다음 $12.5 \mathrm{mM} \mathrm{CaCl} 20.1 \mathrm{~mL}$ 를 가하고 혼 합 후 다시 20 분 간 배양하였다. 기질로서 $0.1 \mathrm{M}$ acetate 
Table 1. The inhibitory effect of lipoxygenase (\%) for five species of Hydrocotyle

\begin{tabular}{lccccc}
\hline \hline \multirow{2}{*}{ Species } & \multicolumn{5}{c}{ Concentration $(\mathrm{mg} / \mathrm{mL})$} \\
\cline { 2 - 6 } & 0.1 & 0.25 & 0.5 & 1.0 & 2.0 \\
\hline H. ramiflora & 5.83 & 10.49 & 10.96 & 17.86 & 23.54 \\
H. maritima & 8.62 & 25.41 & 34.36 & 35.76 & 39.86 \\
H. nepalensis & 12.35 & 26.34 & 35.71 & 44.15 & 50.58 \\
H. sibthorpioides & 14.69 & 27.74 & 39.44 & 41.68 & 49.65 \\
H. yabei & 14.22 & 21.21 & 26.01 & 33.80 & 35.20 \\
NDGA & 40.3 & 50.6 & 71.1 & 75.8 & 94.3 \\
\hline
\end{tabular}

buffer ( $\mathrm{pH} 3.5)$ 에 녹인 hyaluronic acid $(12 \mathrm{mg} / \mathrm{mL})$ 를 첨가 하여 다시 40 분 간 배양하여 $0.4 \mathrm{~N}$ potassium-tetraborate $0.1 \mathrm{~mL}$ 및 $0.4 \mathrm{~N} \mathrm{NaOH}$ 용액을 $0.1 \mathrm{~mL}$ 반응 혼합물에 첨 가하여 3 분 동안 수조에서 가열한 후 완전히 냉각시켰다. 냉각시킨 반응물에 발색제로 $\mathrm{DMAB}$ 시약 $3 \mathrm{~mL}$ 을 가하여 $37^{\circ} \mathrm{C}$ 에서 20 분간 배양한 다음 $585 \mathrm{~nm}$ 에서 흡광도를 측정 하여 저해활성을 산출하였다.

\section{Xanthine oxidase 저해활성 측정}

Xanthine oxidase 저해활성은 Stirpe and Corte (1969)의 방법에 따라 측정하였다. 일정 농도로 희석한 각 피막이 속 5종 추출물 $0.1 \mathrm{~mL}$ 에 $0.1 \mathrm{M}$ potassium phosphate buffer $(\mathrm{pH} 7.5) 0.6 \mathrm{~mL}$ 와 xanthine $(2 \mathrm{mM})$ 을 녹인 기질액 $0.2 \mathrm{~mL}$ 를 첨가하였다. 여기에 xanthine oxidase $(0.2 \mathrm{U} / \mathrm{mL}) 0.1 \mathrm{~mL}$ 를 가하여 $37^{\circ} \mathrm{C}$ 에서 5 분간 반응시킨 후 $20 \%$ trichloroacetic acid (TCA) $1 \mathrm{~mL}$ 를 가하여 반응을 정지시킨 다음 반응액 에 생성된 uric acid를 $292 \mathrm{~nm}$ 에서 흡광도를 측정하였다. 피막이속 5 종 추출물에 한 xanthine oxidase 저해활성은 시 료의 첨가군과 무첨가군의 흡광도 감소율을 \%로 나타내 었다. 대조군은 ascorbic acid를 추출물 대신 동일한 농도 로 첨가하여 시료군과 동일한 방법으로 측정하였다.

\section{통계분석}

시험 물질의 15-Lipoxygenase (15-LO), Hyaluronidase (HAase), Xanthine oxidase 저해활성을 아래 식으로 계산 하였다.

Inhibition effect $(\%)=(\mathrm{IA}-\mathrm{As}) / \mathrm{IC} \times 100$

여기서 IA는 시료 무첨가군의 흡광도이고, $\mathrm{As}$ 는 시료 용액 첨가군의 흡광도이다.

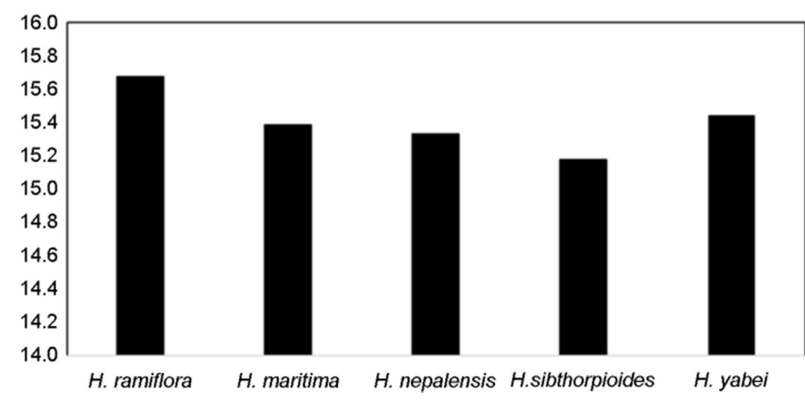

Fig. 1. The $50 \%$ inhibition $\left(\mathrm{EC}_{50}\right)$ of lipoxygenase in five Hydrocotyle species on $1.0 \mu \mathrm{g} / \mathrm{mL}$.

\section{S: $\Delta$ absorbance of sample C: $\Delta$ absorbance of control}

효소 활성의 $50 \%$ 저해 농도 $\left(\mathrm{EC}_{50}\right)$ 값을 logarithmic regression analysis으로 산출하였다. 유의성 검증은 분산분석 (ANOVA)을 시행하였고 $P<0.05$ 수준에서 Duncan's multiple range test에 따라 분석하였다.

\section{결 과}

LOX에 대한 저해작용은 5종 모두 농도 의존적으로 나 타났다(Table 1). LOX 저해정도는 추출농도 $0.1 \mathrm{mg} / \mathrm{mL}$ 일 경우 H. ramiflora에서 $5.8 \%$ 로 가장 낮았고, H. sibthorpioides에서 $14.7 \%$ 로 가장 높았다. $0.25 \mathrm{mg} / \mathrm{mL}$ 일 경우도 유사한 경향을 나타내었다. $1.0 \mathrm{mg} / \mathrm{mL}$ 일 경우 H. nepalensis 에서 $44.2 \%$ 로 가장 높았다. H. ramiflora를 제외할 경우 농 도 증가에 따른 $\mathrm{LOX}$ 소거능은 유의성은 없었다 $(P<0.05)$. 또한, $\mathrm{LOX}$ 에 대한 저해작용은 $2.0 \mathrm{mg} / \mathrm{mL}$ 일 경우에도 $50.6 \%$ 이내로 크게 높지 않았다. NDGA을 대조군으로 사 용했을 때 $0.1 \mathrm{mg} / \mathrm{mL}$ 에서는 약 $40.3 \%, 2.0 \mathrm{mg} / \mathrm{mL}$ 에서는 $94.3 \%$ 의 저해 효과를 나타내었다.

Hyaluronidase 저해효과는 추출농도 $0.1 \mathrm{mg} / \mathrm{mL}$ 일 경우 H. sibthorpioides에서 $1.2 \%$ 로 가장 낮았고, H. ramiflora에 서 $9.7 \%$ 로 가장 높았다(Table 2). $0.25 \mathrm{mg} / \mathrm{mL}$ 일 경우 $H$. yabei에서 $11.9 \%$ 로 가장 높았다. $0.5 \mathrm{mg} / \mathrm{mL}$ 일 경우 $H$. ramiflora에서 $16.0 \%$ 로 가장 높았다. $1.0 \mathrm{mg} / \mathrm{mL}$ 일 경우 $H$. ramiflora에서 가장 높았다. 전반적으로 H. ramiflora에서 가장 높은 저해활성을 나타내었고, H. nepalensis에서 가장 낮았다(Fig. 2). Hyaluronidase에 대한 저해 작용은 농도 의 존적이었지만, $2.0 \mathrm{mg} / \mathrm{mL}$ 일 경우에도 $23 \%$ 를 초과하지 않 아 저해 활성이 전반적으로 높지 않았다.

Xanthine oxidase 저해효과는 추출농도 $0.1 \mathrm{mg} / \mathrm{mL}$ 일 경 
Table 2. The inhibitory effect of hyaluronidase (\%) for five species of Hydrocotyle

\begin{tabular}{lcrrrc}
\hline \hline \multirow{2}{*}{ Species } & \multicolumn{5}{c}{ Concentration $(\mathrm{mg} / \mathrm{mL})$} \\
\cline { 2 - 6 } & \multicolumn{1}{c}{0.1} & \multicolumn{1}{c}{0.25} & \multicolumn{1}{c}{0.5} & \multicolumn{1}{c}{1.0} & \multicolumn{1}{c}{2.0} \\
\hline H. ramiflora & 9.74 & 11.64 & 15.97 & 17.17 & 22.24 \\
H. maritima & 1.39 & 6.16 & 7.00 & 13.54 & 15.80 \\
H. nepalensis & 3.63 & 5.75 & 6.66 & 8.51 & 12.17 \\
H. sibthorpioides & 1.18 & 7.17 & 8.18 & 11.45 & 14.86 \\
H. yabei & 8.82 & 11.93 & 12.94 & 17.10 & 18.92 \\
DSCG & 28.88 & 43.28 & 65.66 & 76.70 & 78.43 \\
\hline
\end{tabular}

Table 3. The inhibitory effect of xanthine oxidase (\%) for five species of Hydrocotyle

\begin{tabular}{lrrrcc}
\hline \hline \multirow{2}{*}{ Species } & \multicolumn{5}{c}{ Concentration $(\mathrm{mg} / \mathrm{mL})$} \\
\cline { 2 - 6 } & 0.1 & 0.25 & 0.5 & 1.0 & 2.0 \\
\hline H. ramiflora & 9.7 & 27.0 & 40.3 & 70.1 & 80.0 \\
H. maritima & 5.7 & 25.1 & 29.7 & 46.0 & 65.4 \\
H. nepalensis & 4.6 & 9.8 & 19.1 & 40.7 & 52.1 \\
H. sibthorpioides & 2.6 & 11.4 & 13.6 & 35.3 & 43.8 \\
H. yabei & 6.7 & 8.6 & 24.9 & 27.3 & 43.2 \\
Ascorbic acid & 5.7 & 15.2 & 21.9 & 34.1 & 37.5 \\
\hline
\end{tabular}

우 H. sibthorpioides에서 $2.6 \%$ 로 가장 낮았고, H. ramiflora 에서 $9.7 \%$ 로 가장 높았다(Table 3). $0.25 \mathrm{mg} / \mathrm{mL}$ 일 경우 $H$. $y a b e i$ 에서 $6.7 \%$ 로 가장 낮았다. $0.5 \mathrm{mg} / \mathrm{mL}$ 일 경우 $H$. ramiflora에서 $40.3 \%$ 로 가장 높았다. $1.0 \mathrm{mg} / \mathrm{mL}, 2.0 \mathrm{mg} /$ $\mathrm{mL}$ 일 경우 H. ramiflora에서 가장 높았다. 전반적으로 $H$. ramiflora에서 가장 높은 저해활성을 나타내었고, H. sibthorpioides 와 H. yabei 가 $2.0 \mathrm{mg} / \mathrm{mL}$ 에서 $43 \%$ 대로 가장 낮았다. Xanthine oxidase에 대한 저해작용은 농도 의존적이었지만 전반적으로 H. ramiflora와 H. maritima에서는 저해 활성 을 나타내지만 다른 종에서는 크게 높지 않았다(Fig. 3). Xanthine oxidase 저해율은 $2.0 \mathrm{mg} / \mathrm{mL}$ 경우 H. ramiflora가 $80 \%$, H. maritima $65.4 \%$ 로 높게 나타났다. 반면 나머지 3종 은 크게 높지 않아 종간 차이가 유의성을 나타내었다.

\section{고 찰}

LOX는 곡류(밀, 호밀, 귀리, 보리, 옥수수)나 콩과류(대 두, 완두, 녹두, 강낭콩), 감자괴경에 풍부하다(Baysal and Demirdöven, 2007; Lampi et al., 2020). 물푸레나무(Fraxinus rhynchophylla) 추출물 농도 $4.0 \mathrm{mg} / \mathrm{mL}$ 일 때 LOX 저해율

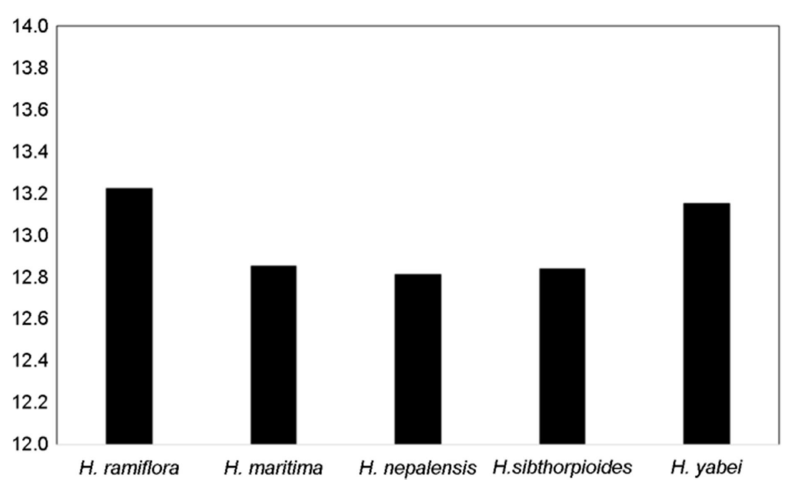

Fig. 2. The $50 \%$ inhibition $\left(\mathrm{EC}_{50}\right)$ of hyaluronidase in five Hydrocotyle species on $1.0 \mu \mathrm{g} / \mathrm{mL}$.

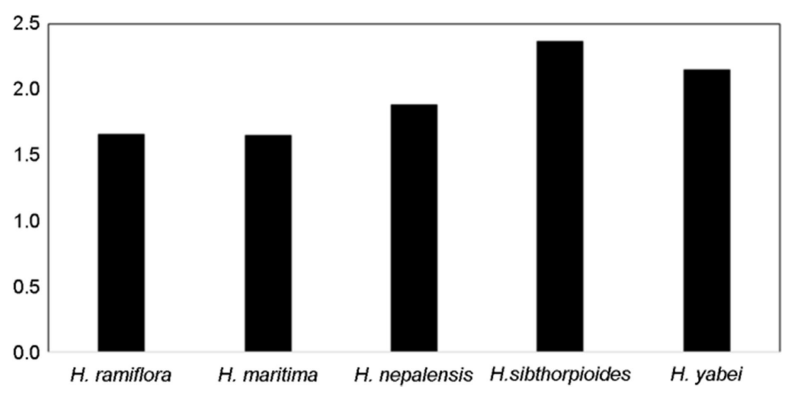

Fig. 3. The $50 \%$ inhibition $\left(\mathrm{EC}_{50}\right)$ of xanthine oxidase in five Hydrocotyle species on $1.0 \mu \mathrm{g} / \mathrm{mL}$.

은 47.3\%였다(Huh et al., 2015). Coumarin umbelliprenin에 서 LOX 저해율은 $47.0 \%$ 였다(Iranshahi et al., 2009). 차나 무(Camellia sinesis), 바위돌꽃(Rhodiola rosea), 모감주나무 (Koelreuteria henryi) 등도 높은 LOX 저해율을 나타내었다 (Chen et al., 2009). 이들 농도와 비교하기 위해 피막이의 추출농도를 $8.0 \mathrm{mg} / \mathrm{mL}$ 로 높일 경우 $\mathrm{LOX}$ 저해율은 잎에 서는 $55.5 \%$ 로 나타내었다(data not shown). Apiaceae 속 식 물에 대한 $\mathrm{EC}_{50}$ 값은 Sandix pectrn-veneris 종을 제외하고 20.0 52.0 $\mu \mathrm{g} / \mathrm{mL}$ 이었다(Loncaric et al., 2021). 피막이속 식 물의 $\mathrm{EC}_{50}$ 값은 $15.1 \sim 15.7 \mu \mathrm{g} / \mathrm{mL}$ 으로 나타나 Apiaceae 속 식물보다 낮은 것으로 조사되었다(Fig. 1).

피막이속 식물의 hyaluronidase에 대한 저해작용은 농도 의존적이었지만, $2.0 \mathrm{mg} / \mathrm{mL}$ 일 경우에도 $21 \%$ 를 초과하지 않아 전반적으로 저해 활성이 높지 않았다(Table 2). Hyaluronidase inhibition에 대한 문헌으로 Garcinia indica의 경 우, 수용액 추출물 $500 \mu \mathrm{g} / \mathrm{mL}$ 에서 $95.7 \%$, 에탄올 추출물 $500 \mu \mathrm{g} / \mathrm{mL}$ 에 대해서 $90.4 \%$ 를 나타내었다(Sahasrabundhe and Deodhar, 2010). Trametes Lactinea의 수용성 추출물에 서 $88.6 \pm 0.11 \%$, 아세톤 추출물은 $88.3 \pm 0.14 \%$ 로 높은 식 
물종이 보고되었다(Yahaya and Don, 2012). 이들은 높은 저해활성을 보였다. 반면에, 섬쑥부쟁이 헥산 분획물은 $10 \mu \mathrm{g} / \mathrm{mL}$ 에서 $17.91 \%$, 에틸아세테이트 분획물은 $10 \mu \mathrm{g} / \mathrm{mL}$ 에서 $24.37 \%$, 부탄올 분획물은 $10 \mu \mathrm{g} / \mathrm{mL}$ 에서 $15.74 \%$, 물 분획물은 $10 \mu \mathrm{g} / \mathrm{mL}$ 에서 $8.75 \%$ 의 저해 효과가 나타났고, 대조군인 (+)-Catechin의 경우, $10 \mu \mathrm{g} / \mathrm{mL}$ 에서 $31.61 \%$ 의 저 해능을 나타내었다(Kim et al., 2010).

Hudaib et al. (2011)이 Lavandula angustifolia Mill. (28.7\% inhibition), Helianthemum ledifolium (L.) Mill. (28.4\%), Majorana syriaca (L.) Kostel. (25.1\%), and Mentha spicata L. (22.5\%) 이 보고한 Xanthine oxidase에 대한 저해효과를 보였으며, $\mathrm{EC}_{50}$ 값은 Salvia spinosa L. $\left(\mathrm{IC}_{50}=53.7 \mu \mathrm{g} / \mathrm{mL}\right)$, Anthemis palestina Boiss. (168.0 $\mu \mathrm{g} / \mathrm{mL})$, Chrysanthemum coronarium $\mathrm{L}$. (199.5 $\mu \mathrm{g} / \mathrm{mL})$, Achillea biebersteinii Afansiev (360.0 $\mu \mathrm{g} / \mathrm{mL})$, Rosmarinus officinalis L. (650.0 $\mu \mathrm{g} / \mathrm{mL})$, Ginkgo biloba L. $(595.8 \mu \mathrm{g} / \mathrm{mL})$ 으로 나타났다. 이는 본 연구 피막이 6종의 결과 저해율 43.2 80.0\%에 비해 낮은 값이다(Table 3).

LOX, Hyaluronidase, Xanthine oxidase에 대한 피막이속 식물의 저해효과는 우리 조상들이 상처가 났을 때 지혈 뿐만 아니라 항염증이나 항알러지에 대한 효과를 나타내 는 성분이 함유되어 있는 것으로 나타났다. 일부 식물은 '풀독'이라 하여 인체에 해로운 성분이나 잎 가장자리에 날카로운 거치가 있어 피부손상을 가져올 수 있다. 함부 로 약용으로 사용되지 못한다. 피막이는 잎 자체가 부드 러울 뿐만 아니라 독성이 보고되지 않아 야외에서 임시 방편으로 지혈로 사용될 수 있음이 일부 입증되었다.

\section{ACKNOWLEDGEMENT}

None

\section{CONFLICT OF INTEREST}

The authors have declared no conflict of interest.

\section{REFERENCES}

Baysal T, Demirdöven A. Lipoxygenase in fruits and vegetables: A review. Enzyme and Microbial Technology. 2007. 40: 491496.

Bertolami CN, Donoff RB. Hyaluronidase activity during open wound healing in rabbits: A preliminary report. Journal of Surgical Research. 1978. 25: 256-259.

Chen CH, Chan HC, Chu YT, Ho HY, Chen PY, Lee TH, Lee CK.
Antioxidant activity of some plant extracts towards xanthine oxidase, lipoxygenase and tyrosinase. Molecules. 2009. 14: 2947-2958.

Duke EJ, Joyce P, Ryan JP. Characterization of alternative molecular forms of xanthine oxidase in the mouse. Biochemical Journal. 1973. 131: 187-190.

Fan YY, Chapkin RS. Importance of dietary gamma-linolenic acid in human health and nutrition. Journal of Nutrition. 1998. 128: 1411-1414.

Farong Yu, Fahong Yu, McGuire PM, Li R, Wang R. Effects of Hydrocotyle sibthorpioides extract on transplanted tumors and immune function in mice. Phytomedicine. 2007. 14: 166171.

Ferrero-Miliani L, Nielsen OH, Andersen PS, Girardin SE. Chronic inflammation: importance of NOD2 and NALP3 in interleukin1beta generation. Clinical and Experimental Immunology. 2007. 147: 227-235.

Ghosh P. The role of hyaluronic acid (hyaluronan) in health and disease: interactions with cells, cartilage and components of synovial fluid. Clinical and Experimental Rheumatology. 1994. 12: $75-82$.

Girish KS, Kemparaju K. The magic glue hyaluronan and its eraser hyaluronidase: a biological overview. Life Sciences. 2007. 80: 1921-1943.

Gilman AG, Goodman LS, Rall TW, Murad F. Goodman and Gilman's the pharmacological basis of therapeutics. 1985. pp. 712-715. Macmillan, New York, USA.

Goggins JF, Fullmer HM, Steffek AJ. Hyaluronidase activity of human gingiva. Archives of Pathology \& Laboratory Medicine. 1968. 85: 272-274.

Gracie JA, Forsey RJ, Chan WL, Gilmour A, Leung BP, Greer MR, Kennedy K, Carter R, Wei XQ, Xu D, Field M, Foulis A, Liew FY, McInnes IB. A proinflammatory role for IL-18 in rheumatoid arthritis. Journal of Clinical Investigation. 1999. 104: 1393-1401.

Handique PJ, Garg M. Evaluation of antioxidant and antimicrobial activity of a medicinal plant Hydrocotyle sibthorpiodes Lam., grown in ne India. International Journal of Pharmaceutical Sciences and Research. 2015. 8: 3524-3529.

Hudaib MM, Tawaaha KA, Mohammad MK, Assaf AM, Issa AY, Alali FQ, Aburjai TA, Bustanji YK. Xanthine oxidase inhibitory activity of the methanolic extracts of selected Jordanian medicinal plants. Pharmacognosy Magazine. 2011. 7: 320-324. Huh MK, Cho KS, Jeon SJ. Inhibitory effect of lipoxygenase and 
DPPH radical scavenging activity of Fraxinus rhynchophylla. European Journal of Advanced Research in Biological and Life Sciences. 2015. 3: 10-16.

Iranshahi M, Askari M, Sahebkar A, Hadjipavlou-Litina D. Evaluation of antioxidant, anti-inflammatory and lipoxygenase inhibitory activities of the prenylated Coumarin umbelliprenin. DARU. 2009. 17: 99-103.

Kim KB, Lee EG, Chai OH, Song CH, Jeong JM. Inhibitory effect of phyto-extract mixture (PEM381) on type I allergic reaction. Journal of the Korean Society of Food Science and Nutrition. 2007. 36: 155-162.

Kim HH, Park GH, Park KS, Lee JY, An BJ. Anti-oxidant and antiinflammation activity of fractions from Aster glehni Fr. Schm. Korean Journal of Microbiology and Biotechnology. 2010. 38: 434-441.

Kinne RW, Bruer R, Stuhlmller B, Palombo-Kinne E, Burmester GR. Macrophages in rheumatoid arthritis. Arthritis Research. 2000. 2: 189-202.

Kuhn H, O'Donnell VB. Inflammation and immune regulation by 12/15- lipoxygenases. Progress in Lipid Research. 2006. 45: 334-356.

Lampi AM, Yang Z, Mustonen O, Piironen V. Potential of faba bean lipase and lipoxygenase to promote formation of volatile lipid oxidation products in food models. Food Chemistry. 2020. 311: 125982

Lawrence T, Willoughby DA, Gilroy DW. Antiinflammatory lipid mediators and insights into the resolution of inflammation. Nature Reviews Immunology. 2002. 2: 787-795.

Lee HJ, Ryu JH. Screening of leukotriene B4 receptor antaginist activity from the herbal drugs. Korean Journal of Pharmacognosy. 2000. 31: 273-279.

Loncaric M, Strelec I, Moslavac T, Subaric D, Pavic V, Molnar M. Lipoxygenase inhibition by plant extracts. Biomolecules. 2021. 11: 152. doi:10.3390/biom11020152

Milando AC, Silva RL, Chu Z, Campochiaro PA, Pandey NB, Popel AS. Suppression of ocular vascular inflammation through peptide-mediated activation of angiopoietin-Tie2 signaling. International Journal of Molecular Sciences. 2020. 21: 5142. doi: 10.3390/ijms21145142.

Natarajan R, Nadler JL. Lipid inflammatory mediators in diabetic vascular disease. Arteriosclerosis, Thrombosis, and Vascular Biology. 2004. 24: 1542-1548.

Reilly KB, Srinivasan S, Hatley ME, Patricia MK, Lannigan J, Bolick DT, Vandenhoff G, Pei H, Natarajan R, Nadler JL, Hedrick CC. 12/15-Lipoxygenase activity mediates inflammatory monocyte /endothelial interactions and atherosclerosis in vivo. J Biol Chem. 2004. 279: 9440-9450.

Reissig JL, Storminger JL, Leloir LF. A modified colorimetric method for the estimation of $\mathrm{N}$-acetylamino sugars. J Biol Chem. 1995. 217: 959-966.

Sahasrabundhe A. Deodhar, M. Anti-hyaluronidase, anti-elastase activity of Garcinia indica. International Journal of Botany. 2010. 6: 299-303.

Samuelsson B, Dahlén SE, Lindgren J, Rouzer CA, Serhan CN. Leukotrienes and lipoxins: Structures, biosynthesis, and biological effects. Science. 1987. 237: 1171-1176.

Stirpe F, Corte ED. The regulation of rat liver xanthine oxidase. Journal of Biological Chemistry. 1969. 244: 3855-3861.

Storch J, Ferber E. Detergent-amplified chemiluminescence of lucigenin for determination of superoxide anion production by NADPH oxidase and xanthine oxidase. Analytical Biochemistry. 1988. 169: 262-267.

Yahaya YA, Don MM. Evaluation of Trametes lactinea extracts on the inhibition of hyaluronidase, lipoxygenase and xanthine oxidase activities in vitro. Journal of Physical Science. 2012. 23: $1-15$.

Yedgar S, Krimsky M, Cohen Y, Flower RJ. Treatment of inflammatory diseases by selective eicosanoid inhibition: A doubleedged sword? Trends in Pharmacological Sciences. 2007. 28: 459-464.

Ziegler DW, Hutchinson HD, Kissling RE. Induction of xanthine oxidase by virus infections in newborn mice. Infection and Immunity. 1971. 3: 237-242.

https://doi.org/10.15616/BSL.2021.27.4.277

Cite this article as: Moon $\mathrm{SH}, \operatorname{Lim} \mathrm{Y}$, Huh $\mathrm{MK}$ Lipoxygenases, Hyaluronidase, and Xanthine Oxidase Inhibitory Effects Extracted from Five Hydrocotyle Species. Biomedical Science Letters. 2021. 27: 277-282. 